\title{
ORIGINAL
}

\section{Studies on the Concentration of Radioactive Substances by Plankton, Chlorella pyrenoidosa}

\author{
Yuichiro KImURA, ${ }^{*, * 1}$ Yoshihiro OGaWA, ${ }^{* *, * 1}$ Yoshihide HondA ${ }^{* * *, * 1}$ \\ and Kosuke KatSURAYAMA $* * * *, * 1$
}

(Received March 2, 1990)

(Accepted August 30, 1990)

\begin{abstract}
The uptake and accumulation of ${ }^{60} \mathrm{Co},{ }^{106} \mathrm{Ru}$, and ${ }^{144} \mathrm{Ce}$ by a phytoplankton, chlorella, in seawater, as well as the particulate behavior of these radionuclides, were studied. The following results were obtained. (1) The uptake and accumulation of ${ }^{60} \mathrm{Co}$ increased during the logarithmic growth phase and reached an equilibrium at stationary phase, while those of ${ }^{106} \mathrm{Ru}$ and ${ }^{144} \mathrm{Ce}$ reached the maximum level after one day, followed by reduction during the logarithmic growth phase and an equilibrium at stationary phase. (2) The adsorption of ${ }^{60} \mathrm{Co}$ on dead cells showed a similar pattern to that in live cells, but no change was noted in ${ }^{106} \mathrm{Ru}$ and ${ }^{144} \mathrm{Ce}$. (3) The examination of particulate formation of the radionuclides using HAWP Millipore filters demonstrated that most of ${ }^{60} \mathrm{Co}$ was contained in the filtrate, while about $4 \%$ of ${ }^{106} \mathrm{Ru}$ and $18 \%$ of ${ }^{144} \mathrm{Ce}$ were captured on the filters. (4) The concentration factors were $2.6 \times 10^{2}$ for ${ }^{60} \mathrm{Co}, 3 \times 10^{2}$ for ${ }^{106} \mathrm{Ru}$, and $6.5 \times 10^{3}$ for ${ }^{144} \mathrm{Ce}$. (5) The different patterns for the uptake of ${ }^{60} \mathrm{Co}$ and ${ }^{106} \mathrm{Ru}$ or ${ }^{144} \mathrm{Ce}$ were attributed to the changes of radicactivity concentration due to their particulate formation in the media.
\end{abstract}

KEY WORDS: chlorella, ${ }^{60} \mathrm{Co},{ }^{106} \mathrm{Ru},{ }^{144} \mathrm{Ce}$, biological concentration, particulate formation, seawater

\section{INTRODUCTION}

Radioactive waste disposal is one of the most important problems to protect man and his environments from unwarranted radiation exposure in nuclear industry. Much research effort has been paid to elucidate the fate of radionuclides released into the environments. Especially in hydrosphere, radionuclides would be transferred through various trophic levels to man. Among the organisms living in the environmental hydrosphere, only phytoplanktons play important roles which they can transform inorganic substances into organic substances as a primary producer. Considering that the biological concentration of

* 木村雄一郎, ** 小川喜弘, *** 本田嘉秀, $* * * *$ 桂山幸典

*1 Department of Nuclear Reactor Engineering, Fac. ulty of Science and Technology, Kinki University; 3-4-1 Kowakae, Higashi-Osaka, Osaka 577, Japan. 近畿大学理工学部原子 炉 工学科; 東大阪市小若江 3-4-1 (广577) radionuclides is generally high for phytoplankton and seaweed and that these are eaten by fish and shellfish, we should have interest to these from viewpoint of the kinetics of radioactive substances in the food chain.

RICE et al. ${ }^{1)}$ demonstrated and emphasized the important roles of phytoplankton in the cycling of radioactive substances. It has been pointed out that not only physical adsorption of radioactive substances on dead plankton but also absorption of radioactive substances during their lifetime play significant roles in the migration of radioactive substances in seawater. ${ }^{2)}$

Because of the accumulation of radioactive substances in fresh water (rivers, lakes and marshes) plankton or those in the surface layer of sea, the migration of plankton into different levels of the food chain as a prey or the precipitation of dead plankton would affect the distribution of various radioactive substances in water..$^{3-5}$ HARVEY, ${ }^{6)}$ GOLDBERG $^{7}$ and HAYWARD et al. ${ }^{8}$ 
reported that phytoplankton takes up iron in inorganic particulate or colloidal directly from seawater. Noting that chelating agents (EDTA, etc.) promote the growth of phytoplankton, JOHNSTON $^{9)}$ and IWASAKI ${ }^{10)}$ claimed that phytoplankton takes up iron which has become soluble following its complex with chelating agents in seawater.

It seems plausible that the physical and chemical properties of radioactive substances in water will affect their uptake by plankton and other organisms. However, concentration of radioactive substances by plankton seems to vary according to the characteristics of radioactive substance and plankton in question. In some cases, radioactive substances seem to be concentrated by plankton chiefly by means of physico-chemical adsorption onto their cell surface, while in other cases radioactive substances seem to be actively absorbed and accumulated by plankton through their metabolic activity.

In addition, the concentration of radioactive substances by plankton may vary according to the growth stage of the plankton.

In a series of studies by RICE et al. ${ }^{11,12)}$ and many other investigators, ${ }^{3-26,28-30}$ ) uptake of radioactive substances has been compared among cultured plankton of various species. However, the kinetics of radioactive substances by phytoplankton has not yet been sufficiently clarified from the viewpoint of multiplication of plankton, and together with the characteristics of radioactive substances in seawater.

Under these circumstances, the authors carried out studies on the kinetics of radioactive substances by analyzing the uptake and accumulation of radioactive cobalt, ruthenium and cerium by cultured chlorella and also examined the particulate behavior of these radioactive substances in seawater.

\section{MATERIALS AND METHODS}

\section{Materials}

(1) Plankton

The chlorella, Chlorella pyrenoidosa used in the present study were collected from the Bay of Tanabe (Wakayama prefecture). They are globular or oval, with a size of 2-12 $\mu \mathrm{m}$. Each chlorella cell proliferates into 4 daughter cells with cell division (Plates 1, 2 and 3).

(2) Radioactive substances
Radioactive cobalt $\left({ }^{60} \mathrm{Co}\right): \mathrm{CoCl}_{2}$ dissolved in $\mathrm{HCl}$, having radioactivity concentration of 8.70 $\mathrm{Bq} / \mathrm{ml}$ with a specific radioactivity of $1.98 \times 10^{9}$ $\mathrm{Bq} / \mathrm{ml}$ and a cobalt concentration of $0.44 \mathrm{mg} / \mathrm{ml}$ (a product of O.R.N.L., U.S.A.).

Radioactive ruthenium $\left({ }^{106} \mathrm{Ru}\right)$ : Chloro complex of ${ }^{106} \mathrm{Ru}$ dissolved in $\mathrm{HCl}$, having a radioactivity concentration of $1.37 \times 10^{8} \mathrm{~Bq} / \mathrm{ml}$ with a specific radioactivity of $3.03 \times 10^{8} \mathrm{~Bq} / \mathrm{ml}$ and a ruthenium concentration of $0.59 \mathrm{mg} / \mathrm{ml}$ (and a product of R.C.C., U.K.).

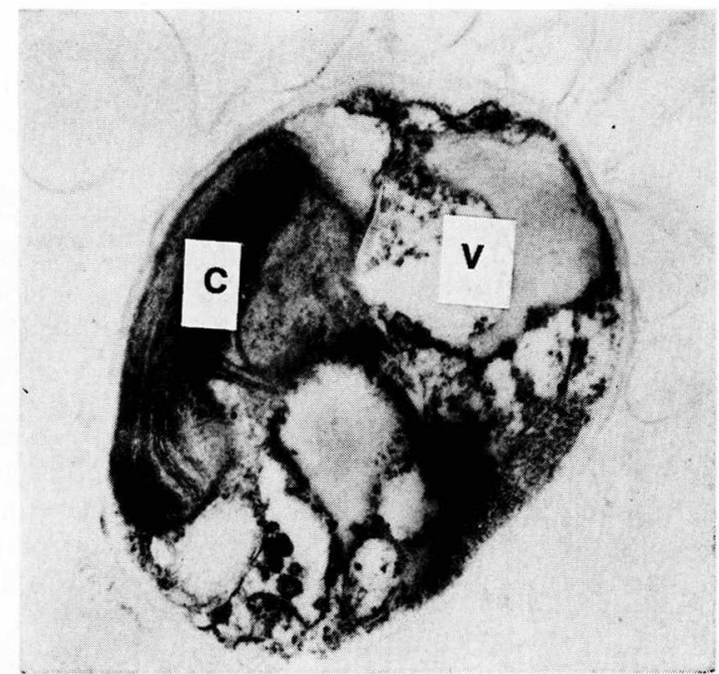

Plate 1 Electron micrograph of chlorella sp. $(\times 37,500) \quad \mathrm{V}$ : vacuoles, C: chloroplast

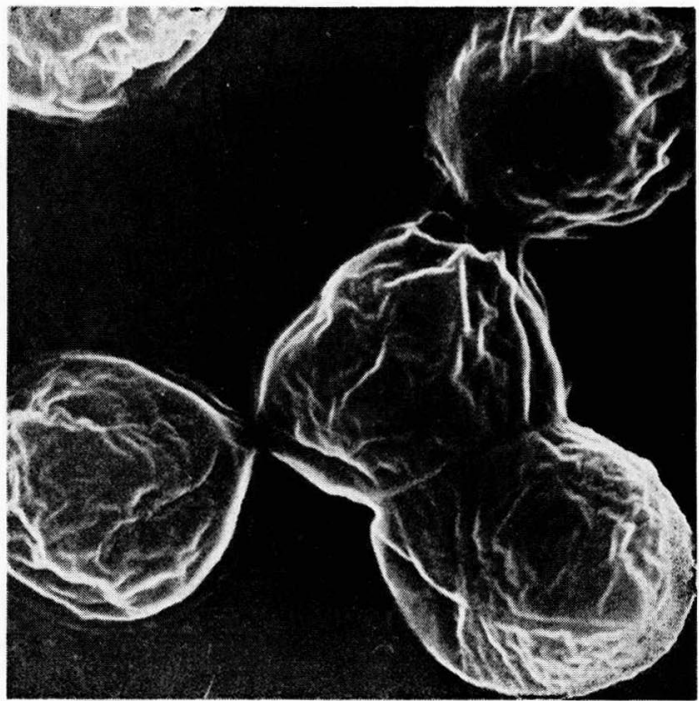

Plate 2 Scanning electron micrograph of chlorella sp. $(\times 18,000)$ 


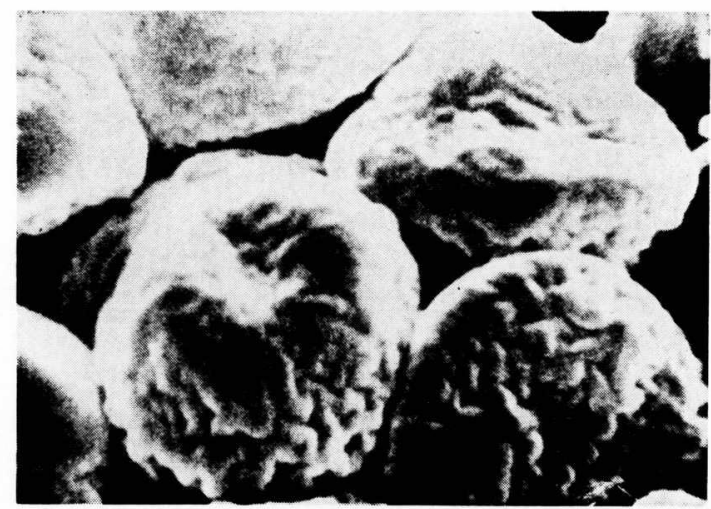

Plate 3 Scanning electron micrograph of chlorella sp. $(\times 20,000)$

Radioactive cerium $\left({ }^{144} \mathrm{Ce}\right): \mathrm{CeCl}_{3}$ dissolved in $\mathrm{HCl}$, having a radioactivity concentration of $1.55 \times 10^{8} \mathrm{~Bq} / \mathrm{ml}$ (carrier free) (a product of R.C.C., U.K.).

In advance, ${ }^{106} \mathrm{Ru}$ was evaporated to dryness twice, using concentrated $\mathrm{HCl}$. Each radionuclide in dilute $\mathrm{HCl}$ solution was added to the liquid culture medium to give a radioactivity concentration of about $62.9 \mathrm{~Bq} / \mathrm{ml}$ before sterilization of the medium.

\section{Instruments and Methods}

(1) Culture of plankton

Artificial seawater was prepared by dissolving Aquamarine ${ }^{\circledR}$ (Yashima Yakuhin Co.) in deionized water. To this seawater was added the following nutrients at the concentrations shown in parentheses: ammonium sulfate $(0.01 \%)$, calcium superphosphate $(0.0015 \%)$ and urea $(0.0005$ $\%$ ). The culture medium thus prepared ( $\mathrm{pH} 8.0$ ) was filtered through a HAWP Millipore filter $(0.45 \mu \mathrm{m})$. A $300 \mathrm{ml}$ aliquot was placed in a shake culture flask of $500 \mathrm{ml}$ with a cotton stopper. The culture media were then sterilized in an autoclave.

The sterilized media were inoculated with chlorella which had reached at stationary growth phase $\left(2.5 \times 10^{8}\right.$ cells $\left./ 5 \mathrm{ml}\right)$, followed by shaking culture at $23 \pm 1{ }^{\circ} \mathrm{C}$, illuminated with four $20 \mathrm{~W}$ daylight lamps.

Chlorella cells which had been treated for several minutes in boiling water were served as heat-killed cells for comparison with live chlorella cells.

(2) Determination of plankton growth

Using a spectrophotometer (Type 138, Hitachi),

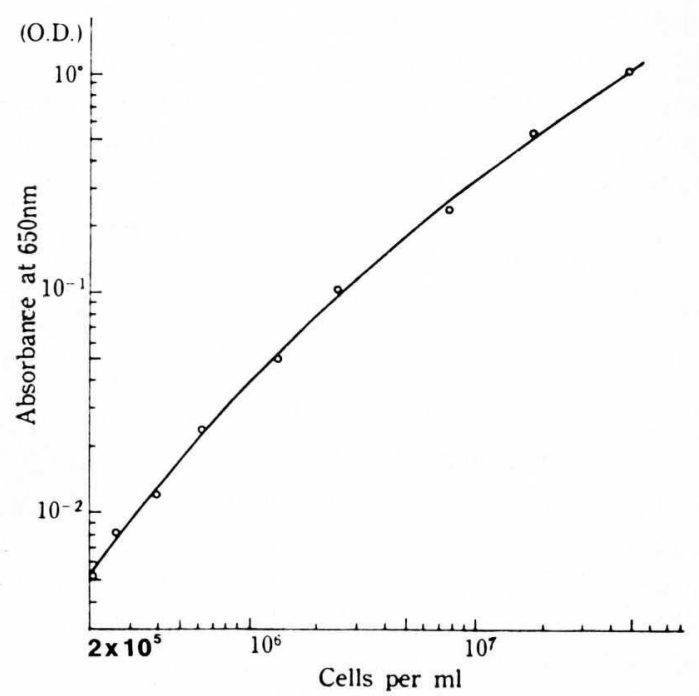

Fig. 1 Absorbance vs. cell concentration of chlorella (O.D. : Optical Density)

the absorbance of the culture at $650 \mathrm{~nm}$ was determined to ascertain the growth of the plankton. The number of cells was calculated using a blood cell counting chamber of Bürker-türk type. The relationship between absorbance and cell count is shown in Fig. 1.

(3) Fractionation of radioactive substances in the culture medium

To assess the physical status of radioactive substances in the medium, the medium was filtered through an HAWP Millipore filter $(0.45$ $\mu \mathrm{m})$, followed by determination of both the radioactivity in the filtrate and the radioactivity adsorbed on the filter for subsequent calculation of the filter sorption rate.

(4) Determination of radioactivity accumulated in plankton

An aliquot $(5 \mathrm{ml})$ of the plankton culture medium was taken with a sterile pipette on several occasions. The sample was filtered with a HAWP $(0.45 \mu \mathrm{m})$ Millipore filter for separation of the plankton. The plankton was dried in a desicator, followed by weight measurement and radioactivity determination using a GM counter.

(5) Calculation of concentration factor

The radionuclide concentration factor for plankton was calculated by ratio of the radioactivity per gram of plankton $(\mathrm{cpm} / \mathrm{g})$ to the radioactivity per $\mathrm{ml}$ of culture filtrate $(\mathrm{cpm} / \mathrm{ml})$, as shown in the following equation. Before this calculation, 
the control culture medium, uninoculated with plankton, was filtered with a Millipore filter, and the radioactivity adsorbed on the filter was determined to obtain the net radioactivity of plankton collected on the filter.

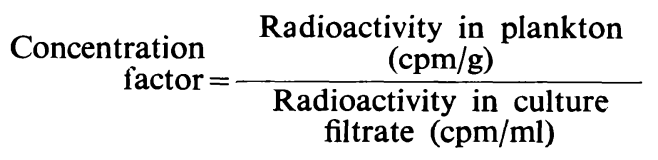

\section{RESULTS}

\section{Growth curve of plankton}

In artificial seawater enriched with nitrogen, phosphorus and other nutrients, chlorella showed a growth curve as shown in Fig. 2. As is noticeable from this figure, the logarithmic growth phase lasted until about 7 days, and the stationary phase was reached after about 10 days from the beginning of the experiment. At the stationary phase, the absorbance at $650 \mathrm{~nm}$ was about 1.0 and the cell count was about $5 \times 10^{7}$ per ml. The growth curve of the chlorella in ${ }^{144} \mathrm{Ce}$-added medium was similar to that in the activity-free control medium. A similar result was also obtained in the ${ }^{60} \mathrm{Co}$ or ${ }^{106} \mathrm{Ru}$-added medium.

2. Accumulation of radioactive substances by plankton

In the course of growth and proliferation of chlorella in the medium (seawater), radioactive substances were taken up and accumulated by chlorella as shown in Fig. 3. As is noticeable

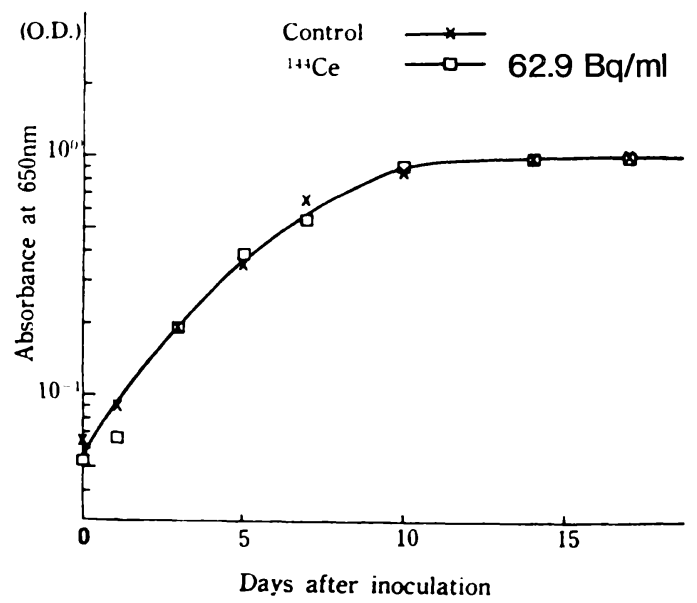

Fig. 2 Population growth curve of chlorella (shake culture) (O.D.: Optical Density). In abscissa, 0 day denotes $6 \mathrm{hr}$ after inoculation. from this figure, the radioactivity per unit weight of plankton in ${ }^{60} \mathrm{Co}$-added medium showed a pattern resembling the cell growth curve. That is to say, the uptake of ${ }^{60} \mathrm{Co}$ by the chlorella increased at logarithmic growth phase and reached an equilibrium at stationary phase. In ${ }^{106} \mathrm{Ru}$ - or ${ }^{144} \mathrm{Ce}$-added medium, on the other hand, the uptake of the radioactivity by the chlorella reached the maximum level after one day and took a declining course during the logarithmic growth phase, attaining an equilibrium at stationary phase. Sorption of ${ }^{60} \mathrm{Co}$ on heat-killed cells gradually reached equilibrium with time, while sorption of ${ }^{106} \mathrm{Ru}$ or ${ }^{144} \mathrm{Ce}$ on heat-killed cells showed no change with time.

As shown in Fig. 3, the level of ${ }^{60} \mathrm{Co}$ in the culture filtrate remained almost unchanged throughout the culture period, while those of ${ }^{106} \mathrm{Ru}$ and ${ }^{144} \mathrm{Ce}$ took a declining course until $5-7$ days, followed by the attainment of an equilibrium. Figure 4 shows the patterns of ${ }^{60} \mathrm{Co},{ }^{106} \mathrm{Ru}$ and ${ }^{144} \mathrm{Ce}$ levels per live cell. These patterns were almost similar to those of uptake of the radionuclides per unit weight of chlorella cells as shown in Fig. 3. These results seem to be closely related to the changes of the radioactivities in the culture media, that is, the decrease in ${ }^{60} \mathrm{Co}$ was almost

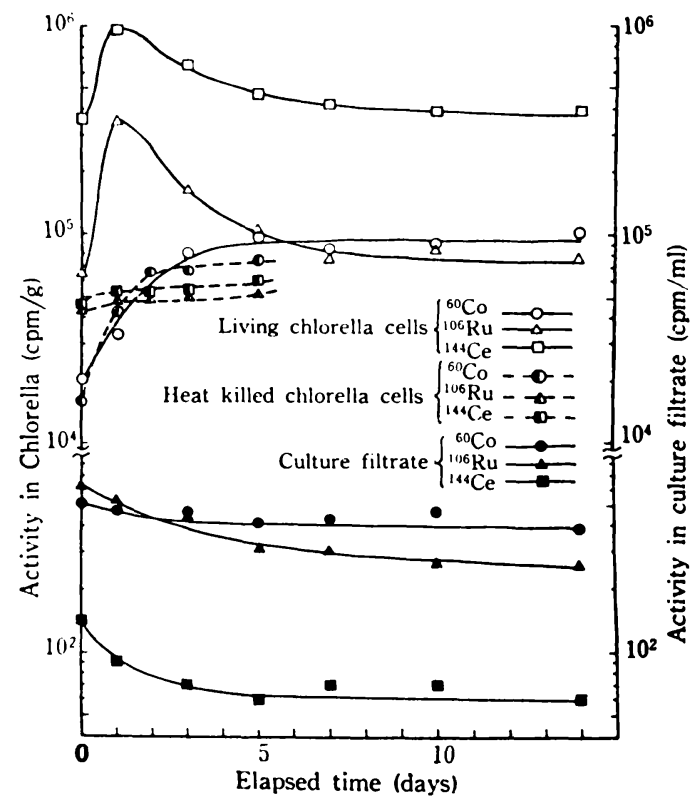

Fig. 3 Uptake of radionuclides by chlorella. In abscissa, 0 day denotes $6 \mathrm{hr}$ after inoculation. 
negligible, while initial decrease in ${ }^{106} \mathrm{Ru}$ or ${ }^{144} \mathrm{Ce}$ was somewhat remarkable and then reached an equilibrium. Therefore, the accumulation of ${ }^{60} \mathrm{Co}$ by the Chlorella approached asymptotically an equilibrium with elapsed time, while that of ${ }^{106} \mathrm{Ru}$ or ${ }^{144} \mathrm{Ce}$ showed the maximum level followed by a decline and then attaining an equilibrium according to the change of the radioactivity in the culture medium.

3. Distribution of radioactive substances in culture medium

The distribution of each radioactive substance in all chlorella cultures is shown in Table 1. The particulate formation of each radionuclide in the seawater medium was studied by filtration with

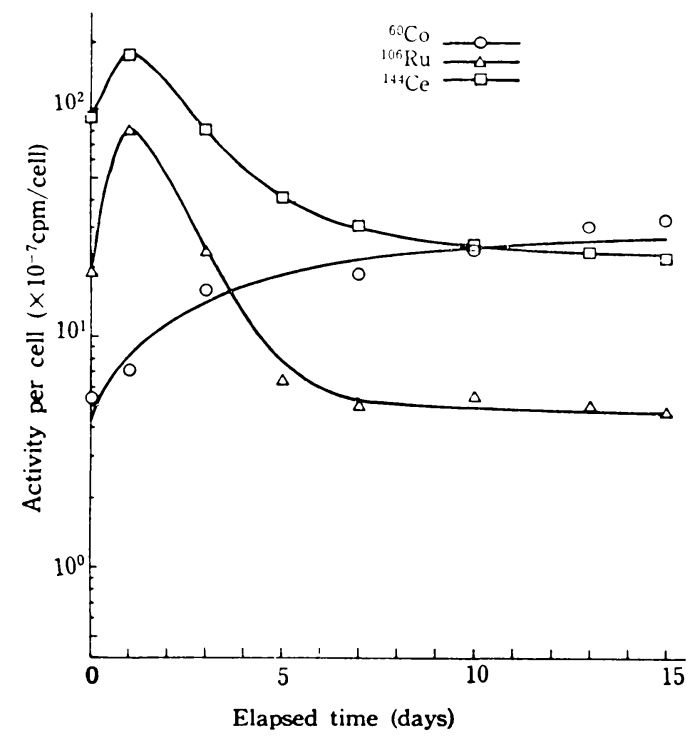

Fig. 4 Activity per cell of chlorella. In abscissa, 0 day denotes $6 \mathrm{hr}$ after inoculation. a HAWP $(0.45 \mu \mathrm{m})$ Millipore filter, and the percentage of ${ }^{60} \mathrm{Co}$ captured by the filter was below $1 \%$ throughout the experimental period (that is to say, the greater part of the radioactivity was found in the filtrate), while the percentage of ${ }^{106} \mathrm{Ru}$ or ${ }^{144} \mathrm{Ce}$ captured by the filter increased with time, attaining an equilibrium (about $4 \%$ for ${ }^{106} \mathrm{Ru}$ and about $18 \%$ for ${ }^{144} \mathrm{Ce}$ ) after $7-10$ days.

The percentage of radioactivity accumulated in chlorella on day 14 of the experimental period was about $8 \%$ for ${ }^{60} \mathrm{Co}$ and about $6 \%$ for ${ }^{106} \mathrm{Ru}$, while it was as large as about $50 \%$ for ${ }^{144} \mathrm{Ce}$. This result indicates that the percentage of radioactivity taken up and accumulated by chlorella is appreciably larger for ${ }^{144} \mathrm{Ce}$ than for ${ }^{60} \mathrm{Co}$ or ${ }^{106} \mathrm{Ru}$, although the number of the chlorella cell per unit volume of the medium is nearly equal. We have already reported in the previous paper ${ }^{31)}$ that the decrease in radioactivity in culture media due to adsorption onto the wall of the container is small for ${ }^{60} \mathrm{Co}$ but relatively large for ${ }^{106} \mathrm{Ru}$ and ${ }^{144} \mathrm{Ce}$. Therefore, in the logarithmic growth phase where cell division is active, the levels of ${ }^{106} \mathrm{Ru}$ and ${ }^{144} \mathrm{Ce}$ per unit weight of chlorella or per cell are thought to decrease due to increase in the number of cells per unit culture volume and reduction in the radioactivities in the media.

\section{Concentration factor for plankton}

Table 2 shows the change in the concentration factors for ${ }^{60} \mathrm{Co},{ }^{106} \mathrm{Ru}$ and ${ }^{144} \mathrm{Ce}$ calc slated on the basis of the dry weight of chlorella. The pattern of this change was similar to that of the change in the radioactivity per unit weight or per cell. The concentration factor at equilibrium was about $2.6 \times 10^{2}$ for ${ }^{60} \mathrm{Co}$, about $3 \times 10^{2}$ for ${ }^{106} \mathrm{Ru}$ and as large as about $6.5 \times 10^{3}$ for ${ }^{144} \mathrm{Ce}$.

Table 1 Distribution of radionuclides in the culture of chlorella.

\begin{tabular}{|c|c|c|c|c|c|c|c|c|c|}
\hline \multirow{2}{*}{ Days } & \multicolumn{3}{|c|}{ Culture filtrate } & \multicolumn{3}{|c|}{ Chlorella cell } & \multicolumn{3}{|c|}{ Particulate fraction } \\
\hline & ${ }^{60} \mathrm{Co}$ & ${ }^{106} \mathrm{Ru}$ & ${ }^{144} \mathrm{Ce}$ & ${ }^{60} \mathrm{Co}$ & ${ }^{106} \mathrm{Ru}$ & ${ }^{144} \mathrm{Ce}$ & ${ }^{60} \mathrm{Co}$ & ${ }^{106} \mathrm{Ru}$ & ${ }^{144} \mathrm{Ce}$ \\
\hline $0 *$ & 0.998 & 0.965 & 0.800 & 0.001 & 0.030 & 0.090 & 0.001 & 0.005 & 0.110 \\
\hline 1 & 0.996 & 0.958 & 0.610 & 0.002 & 0.030 & 0.260 & 0.002 & 0.012 & 0.130 \\
\hline 3 & 0.986 & 0.960 & 0.540 & 0.011 & 0.026 & 0.380 & 0.003 & 0.014 & 0.080 \\
\hline 5 & 0.985 & 0.950 & 0.420 & 0.011 & 0.032 & 0.430 & 0.004 & 0.018 & 0.150 \\
\hline 7 & 0.975 & 0.920 & 0.360 & 0.019 & 0.046 & 0.480 & 0.006 & 0.034 & 0.160 \\
\hline 10 & 0.964 & 0.906 & 0.326 & 0.028 & 0.059 & 0.494 & 0.006 & 0.035 & 0.180 \\
\hline 14 & 0.916 & 0.902 & 0.320 & 0.075 & 0.063 & 0.500 & 0.009 & 0.035 & 0.180 \\
\hline
\end{tabular}

* In abscissa, 0 day denotes $6 \mathrm{hr}$ after inoculation. 
Table 2 Concentration factors for some radionuclides in chlorella.

\begin{tabular}{|c|c|c|c|c|c|c|c|c|c|}
\hline \multirow{2}{*}{ Days } & \multicolumn{3}{|c|}{$\begin{array}{l}\text { Radioactivity in culture } \\
\text { filtrate }(\mathrm{cpm} / \mathrm{ml})\end{array}$} & \multicolumn{3}{|c|}{$\begin{array}{l}\text { Radioactive concentration } \\
(\mathrm{cpm} / \mathrm{g})\end{array}$} & \multicolumn{3}{|c|}{ Concentration factor (C.F.) } \\
\hline & $\begin{array}{c}{ }^{60} \mathrm{Co} \\
\left(\times 10^{2}\right)\end{array}$ & $\begin{array}{c}{ }^{106} \mathrm{Ru} \\
\left(\times 10^{2}\right)\end{array}$ & $\begin{array}{c}{ }^{144} \mathrm{Ce} \\
\left(\times 10^{2}\right)\end{array}$ & $\begin{array}{c}{ }^{60} \mathrm{Co} \\
\left(\times 10^{4}\right)\end{array}$ & $\begin{array}{c}{ }^{106} \mathrm{Ru} \\
\left(\times 10^{4}\right)\end{array}$ & $\begin{array}{c}{ }^{144} \mathrm{Ce} \\
\left(\times 10^{5}\right)\end{array}$ & $\begin{array}{c}{ }^{60} \mathrm{Co} \\
\left(\times 10^{2}\right)\end{array}$ & $\begin{array}{c}{ }^{106} \mathrm{Ru} \\
\left(\times 10^{2}\right)\end{array}$ & $\begin{array}{c}{ }^{144} \mathrm{Ce} \\
\left(\times 10^{3}\right)\end{array}$ \\
\hline $0 *$ & 5.1 & 6.2 & 1.4 & 2.0 & 6.4 & 3.50 & 0.40 & $1.0_{3}$ & $2.5_{0}$ \\
\hline 1 & 4.7 & 5.3 & 0.9 & 3.3 & 34.0 & 9. $4_{0}$ & $0.7_{0}$ & 6.40 & $10.4_{4}$ \\
\hline 3 & 4. 6 & 4.5 & 0.7 & 8.0 & 16.0 & 6. $3_{0}$ & $1.7_{5}$ & 3. $5_{6}$ & 9. $0_{0}$ \\
\hline 5 & 4. 1 & 3.1 & 0.6 & 9.6 & 10.5 & 4. 60 & 2. $3_{4}$ & 3. 39 & $7.6_{7}$ \\
\hline 7 & 4. 3 & 3.0 & 0.7 & 8.4 & 7.5 & 4. $22_{1}$ & $1.9_{5}$ & 2. 50 & 6. $0_{1}$ \\
\hline 10 & 4.7 & 2.6 & 0.7 & 9.0 & 8.3 & $3.8_{0}$ & 1. $9_{2}$ & 3. 19 & $5.4_{3}$ \\
\hline 14 & 3.9 & 2.6 & 0.6 & 10.2 & 7.8 & 3. $9_{0}$ & 2.62 & 3. $0_{0}$ & $6.5_{0}$ \\
\hline
\end{tabular}

C.F. $=C_{\mathrm{b}} / C_{\text {w. }}$

$C_{\mathrm{b}}:$ Radioactive concentration $(\mathrm{cpm} / \mathrm{g})$.

$C_{\text {w }}$ : Radioactivity in culture filtrate $(\mathrm{cpm} / \mathrm{ml})$.

* In abscissa, 0 day denotes $6 \mathrm{hr}$ after inoculation.

\section{DISCUSSION}

In the environmental hydrosphere, sorption of radioactive substances by suspended matter as well as their agglutination and sedimentation play a major role in the kinetics of radioactive substances in the hydrosphere. In the case of inorganic suspended matter, sorption of radioactive substances occurs through physical adsorption, ion exchange or chemical coordination (complex formation). Of many components of the ecosystem in the hydrosphere, suspended organic matter, especially phytoplankton, as a primary producer, is known to play an important role in the cycling of substances in the hydrosphere.

The growth and proliferation rate of plankton are affected by various factors. POLIKARPov et al., ${ }^{24)}$ who studied the influence of ${ }^{35} \mathrm{~S}$ on the cell division rate of a marine unicellular alga, Prorocentrum micans, found that the number of cells at a radioactivity of $3.03 \times 10^{3} \mathrm{~Bq} / \mathrm{ml}$ was smaller than that under the control conditions. In the present study, the growth and proliferation of chlorella were hardly affected by ${ }^{60} \mathrm{Co},{ }^{106} \mathrm{Ru}$ or ${ }^{144} \mathrm{Ce}$ at the level of $62.9 \mathrm{~Bq} / \mathrm{ml}$. In the previous studies ${ }^{31}$ ) on the uptake and accumulation of ${ }^{59} \mathrm{Fe},{ }^{60} \mathrm{Co}$ and ${ }^{89} \mathrm{Sr}$ by a marine diatom and Chlamydomonas in modified Miquel's medium containing these radionuclides $(370-0.37 \mathrm{~Bq} / \mathrm{ml})$, no any radiation effect was found on the growth and proliferation of these organisms.

In the course of growth and proliferation of chlorella, radioactivity levels per unit weight of plankton in ${ }^{60} \mathrm{Co}$ added medium showed a pattern resembling the cell growth curve. That is to say, the uptake of ${ }^{60} \mathrm{Co}$ by the chlorella increased in the logarithmic growth phase and reached an equilibrium at the stationary phase. In ${ }^{106} \mathrm{Ru}-$ or ${ }^{144} \mathrm{Ce}$-added medium, on the other hand, the uptake of the radioactivity by the chlorella reached the maximum level after one day and took a declining course during the logarithmic growth phase, attaining an equilibrium in the stationary phase.

RICE et al. ${ }^{12)}$ who studied the uptake and accumulation of ${ }^{144} \mathrm{Ce}$ (in the form of a nitrate) by a marine planktonic diatom, Nitzschia sp., reported a similar result.

The finding that the uptake and accumulation of ${ }^{60} \mathrm{Co}$ by chlorella were different from those of ${ }^{106} \mathrm{Ru}$ and ${ }^{144} \mathrm{Ce}$ by chlorella may be to some extent related to the differences in nutritional requirement among these elements, but it is undoubtedly more greatly attributable to the differences in the form of these elements in the seawater. That is to say, in the logarithmic growth phase where cell division was active, the number of chlorella cells per unit volume of medium increased and the radioactivity in the medium decreased, especially in the cases of ${ }^{106} \mathrm{Ru}$ and ${ }^{144} \mathrm{Ce}$. Affected by these changes of radioactivities in the media, obvious difference was found between the pattern of uptake and accumulation of ${ }^{60} \mathrm{Co}$ (which is chiefly present as a soluble, ionic form) and those of ${ }^{106} \mathrm{Ru}$ and ${ }^{144} \mathrm{Ce}$ (which are present in the form of colloids or particulates). 
Rice et al.,12) who studied the influence of the number of cells on the uptake and accumulation of ${ }^{144} \mathrm{Ce}$ by a plankton, Nitzschia sp., estimated that in a plankton population at natural density, the amount of ${ }^{144} \mathrm{Ce}$ immediately taken up by plankton in seawater is not very large.

However, in the present study at higher cell density than natural one, the percentage of radioactivity found in chlorella cells at equilibrium was as large as about $50 \%$ for ${ }^{144} \mathrm{Ce}$, compared with about $7 \%$ for ${ }^{60} \mathrm{Co}$ and about $6 \%$ for ${ }^{106} \mathrm{Ru}$.

This result indicates that, the uptake and accumulation of ${ }^{144} \mathrm{Ce}$ by chlorella are appreciably larger than those of ${ }^{60} \mathrm{Co}$ and ${ }^{106} \mathrm{Ru}$. It has been reported elsewhere that $\mathrm{Zn}, \mathrm{Co}, \mathrm{Cu}, \mathrm{Mn}$, $\mathrm{Ru}$, etc. are concentrated to a very large degree $\left(10^{2}-10^{4}\right.$ times) by live or dead planktonic cells. ${ }^{27,28)}$

With regard to algae, RICE ${ }^{11)}$ compared the accumulation of radioactive strontium between live and dead chlorella cells (the latter killed by treatment with glacial acetic acid or heat treatment). Timofeeva et al., ${ }^{29}$ ) found in their experiment that heat-killed algae were able to adsorb an equal or larger amount of ${ }^{90} \mathrm{Sr}$ in comparison with live algal cells. $\mathrm{SAEKI}^{30)}$ reported that dead algal cells had a larger affinity for ${ }^{60} \mathrm{Co}$ and ${ }^{65} \mathrm{Zn}$ in comparison with live algal cells.

As is noticeable from Fig. 3, the present study disclosed that ${ }^{60} \mathrm{Co},{ }^{106} \mathrm{Ru}$ and ${ }^{144} \mathrm{Ce}$ were also adsorbed by dead cells, and that the ${ }^{60} \mathrm{Co}$ sorption pattern for dead cells resembled that for live cells. On the other hand, ${ }^{106} \mathrm{Ru}$ and ${ }^{144} \mathrm{Ce}$ sorption levels showed no changes with time. Comparing the concentrations for ${ }^{60} \mathrm{Co}$ and ${ }^{106} \mathrm{Ru}$, no large difference was noted between dead and live cells. However, the ${ }^{144} \mathrm{Ce}$ concentration was markedly greater in live cells than in dead cells as shown in Fig. 3.

With regard to the radionuclide concentration factor (C. F.) for marine phytoplankton (green algae, red algae and diatoms), the following tendency has been reported ${ }^{30)}:{ }^{65} \mathrm{Zn}$ (C. F.: $10^{4}-$ $\left.10^{5}\right)>{ }^{32} \mathrm{P}\left(\right.$ C. F.: $\left.10^{4}\right)>{ }^{51} \mathrm{Cr}\left(\mathrm{C}\right.$. F.: $\left.10^{3}\right)>{ }^{60} \mathrm{Co}(\mathrm{C}$. F.: $\left.10^{2}\right)>{ }^{131}$ I(C. F.: $\left.10-10^{2}\right)>{ }^{137}$ Cs (C. F.: 10).

In the present study, the concentration factors at an equilibrium of accumulation were as follows: about $2.6 \times 10^{2}$ for ${ }^{60} \mathrm{Co}$, about $3 \times 10^{2}$ for ${ }^{106} \mathrm{Ru}$ and about $6.5 \times 10^{3}$ for ${ }^{144} \mathrm{Ce}$. Of these values, that for ${ }^{60} \mathrm{Co}$ was equal to the value given in the above-mentioned report for phytoplankton.

Electron microscopic observation of ultrathin sections of chlorella cells, as shown in Plate 1 (microstructure of the cell) and Plates 2 and 3 (scanning electron micrographs of the cell surface), disclosed that the surface of chlorella cells has quite a rough structure.

Radioactive substances, which are present in the form of ions in the hydrosphere, could be taken into the cytoplasm of chlorella through the cell surface, while colloidal or particulate radioactive substances seem to chiefly adsorb or adhere onto the cell surface.

The present study disclosed that the mechanism responsible for uptake of ${ }^{60} \mathrm{Co}$ (which is present as a soluble, ionic form in the hydrosphere) is different from that for ${ }^{106} \mathrm{Ru}$ and ${ }^{144} \mathrm{Ce}$ (which are present in the form of colloidal or particulates) considering from the behavior of particulate formation of the radionuclides in the culture medium.

\section{CONCLUSIONS}

The uptake and accumulation of ${ }^{60} \mathrm{Co},{ }^{106} \mathrm{Ru}$ and ${ }^{144} \mathrm{Ce}$ by a phytoplankton, chlorella in seawater, as well as the particulate behavior of these radionuclides were studied. The following results were obtained.

(1) Under the radioactivity level of $62.9 \mathrm{~Bq} / \mathrm{ml}$ in the medium, the growth and proliferation of chlorella were not affected at all.

(2) The uptake and accumulation of ${ }^{60} \mathrm{Co}$ increased during the logarithmic growth phase of chlorella and reached an equilibrium at stationary phase, while those of ${ }^{106} \mathrm{Ru}$ and ${ }^{144} \mathrm{Ce}$ reached the maximum level after one day, followed by reduction during the logarithmic growth phase and an equilibrium at stationary phase, according to the changes of the radioactivities in their media.

(3) The adsorption of ${ }^{60} \mathrm{Co}$ on dead chlorella cells showed a similar pattern to that in live cells, but no change was noted for the cases of ${ }^{106} \mathrm{Ru}$ and ${ }^{144} \mathrm{Ce}$ with time.

(4) The examination of particulate formation of the radionuclides using HAWP Millipore filters $(0.45 \mu \mathrm{m})$ demonstrated that ${ }^{60} \mathrm{Co}$ captured by the filter remained below $1 \%$ throughout the experimental period, while ${ }^{106} \mathrm{Ru}$ and ${ }^{144} \mathrm{Ce}$ increased with time and reached an equilibrium (about $4 \%$ for ${ }^{106} \mathrm{Ru}$ and about $18 \%$ for ${ }^{144} \mathrm{Ce}$ ) after 7-10 days.

(5) On the 14th day of culture, radioactivities accumulated in chlorella were about $8 \%$ for ${ }^{60} \mathrm{Co}$, 
about $6 \%$ for ${ }^{106} \mathrm{Ru}$ and as large as about $50 \%$ for ${ }^{144} \mathrm{Ce}$.

(6) The concentration factors at an equilibrium of accumulation were $2.6 \times 10^{2}$ for ${ }^{60} \mathrm{Co}$, $3 \times 10^{2}$ for ${ }^{106} \mathrm{Ru}$ and $6.5 \times 10^{3}$ for ${ }^{144} \mathrm{Ce}$.

(7) The different mechanisms for the uptake of ${ }^{60} \mathrm{Co}$ and ${ }^{106} \mathrm{Ru}$ or ${ }^{144} \mathrm{Ce}$ were considered according to their particulate formation in the media.

\section{REFERENCES}

1) T.R. RICE; Formal discussion on "Accumulation of mixed fission products by marine organisms," The Second International Conference on Water Pollution Research, Tokyo (1964).

2) M. SAEKI; Radioisotopes, 19, 328 (1970).

3) T. Sugihara and V.T. Bowen; Radioisotopes in the Physical Sciences and Industry, IAEA, 57 (1962).

4) C. Osterberg, A.G. Gavey and H. Curl; Nature, 200, 1276 (1963).

5) B.H. Ketchum and V.T. Bowen; Biological Factors Determining the Distribution of Radioisotopes in the Sea, Contribution No. 968, Woods Hole Oceanographic Inst. (1968).

6) H.W. Harvey; J. Mar. Biol. Assoc. U. K., 22, 203 (1937).

7) E.D. Goldberg; Biol. Bull., 102, 243 (1952).

8) J. Hayward; J. Mar. Biol. Assoc. U. K., 45, 295 (1968).

9) R. Johnston; J. Mar. Riol. Assoc. U. K., 44, 87 (1967).

10) H. Iwasaki; Bull. Jpn. Soc. Sci. Fish., 33, 1072 (1967).

11) T.R. Rice; Limnol. Oceanogr., 1, 123 (1956).

12) T.R. RiCE and V.M. Willis; Limnol. Oceanogr., 4, 277 (1959).

13) NAS-NRC; "The Effects of Atomic Radiation on Oceanography and Fisheries," NAS-NRC, Washington, D.C., Publ. 551 (1957).

14) B.H. Ketchum and V.T. Bowen; Proc. 2nd Int. Conf. Peaceful Uses of Atomic Energy, Geneva, 18, P/404, U.N., New York (1958).

15) NAS-NRC; Radioactive Waste Disposal from Nuclear Powered Ships, NAS-NRC, Washington, D.C., Publ. 558 (1959).
16) IAEA; Safety Series No. 5, Radioactive Wastes Disposal into the Sea, IAEA, Vienna (1961).

17) IAEA; Disposal of Radicactive Wastes intc Sea, Oceans and Surface Waters, IAEA, Vienna (1966)

18) G.G. Polikar Pov; "Radicecology of Aquatic Organisms," Nerth Holland Publ. Co., Amsterdam (1966).

19) Nuclear Safety Research Association of Japan; Report from the Biological Subcommittee of the Marine Disposal Special Committee (1967).

20) Atomic Energy Safety Association; Report from the Committee for Basic Investigation on Countermeasures against Marine Pollution (1987).

21) Atomic Energy Safety Association; Report from the Committee for Basic Investigation on Countermeasures against Marine Pollution (1967).

22) M. SAEKI; Report from the Atomic Energy Safety Association, 13858 (1968).

23) E.P. Odum; "Fundamentals of Ecology," 2nd Edition, 452, W.E. Saunders Corp., London (1969).

24) G.G. Polikarpov and L.A. Lanskaya; 1961, Cited from G.G. Plikarpov (1966).

25) Y. Honda and Y. Kimura; Report of the Results of a Study on Peaceful Uses of Atomic Energy, 7, 191, Agency of Sciences and Technology (1967).

26) Y. Honda and Y. Kimura; Annual Report of the Kinki University Atomic Energy Research Institute, 9, 19 (1971).

27) G.G. Polikarpov; Radioecology of Aquatic Organisms, "North Hoiland Publ. Co., Amsterdam (1966).

28) M. Saeki, N. TaKada and T. Umezu; Annual Report of the Nacional Institute of Radiological Sciences 1-4 (for years 1963-1966) (1967).

29) N.A. Timoreeva and N.V. Kullov; "Radioecological Concentration Processes," Pergamon Press, Oxford, p. 835 (1966).

30) M. SAeKI; Marine Disposal of Radioactive Wastes, Genshiryoku Kogyo, 13, 38 (1967).

31) Y. Kimura, Y. Ogawa, Y. Honda and K. Katsurayama; Annual Report of the Kinki University Atomic Energy Research Institute, 17, 21 (1980). 